Review Article

\title{
A Review on Pyroprocessing Techniques for Selected Wastes Used for Blended Cement Production Applications
}

\author{
Protus Nalobile $\mathbb{D}^{1},{ }^{1}$ Jackson Muthengia Wachira, ${ }^{2}$ Joseph Karanja Thiong'o, ${ }^{1}$ \\ and Joseph Mwiti Marangu $\mathbb{1}^{3}$ \\ ${ }^{1}$ Department of Chemistry, Kenyatta University, Nairobi, Kenya \\ ${ }^{2}$ Department of Physical Sciences, University of Embu, Embu, Kenya \\ ${ }^{3}$ Department of Physical Sciences, Meru University of Science \& Technology, Meru, Kenya
}

Correspondence should be addressed to Protus Nalobile; nalobilep@yahoo.com and Joseph Mwiti Marangu; jmarangu2011@ gmail.com

Received 9 February 2020; Revised 11 July 2020; Accepted 24 July 2020; Published 17 August 2020

Academic Editor: Giulio Castori

Copyright (c) 2020 Protus Nalobile et al. This is an open access article distributed under the Creative Commons Attribution License, which permits unrestricted use, distribution, and reproduction in any medium, provided the original work is properly cited.

\begin{abstract}
Pyroprocessing is an important stage in cement manufacturing. In this process, materials are subjected to high temperatures so as to cause a chemical or physical change. Its control improves efficiency in energy utilization and hence enhances production for good quality assurance. Kilns used in cement manufacturing are complex in nature. They have longer time constants, and raw materials used have variable properties. They are therefore difficult to control. Additionally, the inclusion of various alternative fuels in burning makes the process more complex as the fuel characteristics remain inconsistent throughout the kiln operation. Fuel intensity standards for kilns using fuel oil are very high, ranging from $2.9 \mathrm{GJ}$ to $7.5 \mathrm{GJ} /$ ton of clinker produced. Grinding of clinker consumes power in the range of $2.5 \mathrm{kWh} /$ ton of clinker produced. These and other pyroprocessing parameters make cement production costly. The pyroprocessing process in kilns and the grinding technologies therefore have to be optimized for best processing. This paper discusses the cement manufacturing and grinding processes. The traditional kiln technologies and the current and emerging technologies together with general fuel and energy requirements of cement manufacturing have been discussed. From the discussion, it has been established that the cement manufacturing and grinding technologies are capitalintensive investments. The kiln processes are advanced and use both electricity and natural fuels which are expensive and limited factors of production. The raw materials used in cement manufacturing are also limited and sometimes rare. The calcination of the raw materials requires external energy input which has contributed to the high cost of cement especially to low-income population in the developing countries. Self-calcining materials, in which the pozzolanic materials burn on their own, are potential pozzolanic materials with great potential to lower the cost of cement production. Such materials, as shown from the previous research study, are rice husks, broken bricks, spent bleaching earth, and lime sludge. There is a need, therefore, for research to look into ways of making cement using kiln processes that would use this property. This will be cost-effective if successful. It can be done at microand small-scale enterprise.
\end{abstract}

\section{Introduction}

Cement is the most commonly used binder in concrete production all over the world. Its production is however expensive due to high amount of energy used in its manufacture. It is therefore out of reach of a majority of the world population [1]. The high cost of cement especially in developing countries is mainly due to the high energy demand during the clinkerisation process. During clinkerisation, temperatures in excess of $1450^{\circ} \mathrm{C}$ are employed [2]. This makes the resultant cement unaffordable to low-income earners. This has subsequently led to mushrooming of slums in most parts of Africa.

Researchers have been exploring ways of manufacturing less costly cement using supplementary cementitious materials (SCM). These have materials that include industrial 
byproducts (fly ash, slag, silica fume, and acetylene sludge lime) and agricultural wastes such as rice husk, palm oil fuel ash, and sugarcane bagasse. These materials have been shown to have cementitious properties and are known as pozzolana [3-7]. There are two types of pozzolana, natural and artificial. Natural pozzolanas are materials that will react with lime in the presence of water to form cementitious properties in their natural form at ambient temperature. Examples of natural pozzolana are volcanic tuff and diatomaceous earths. Artificial pozzolanas have to be processed before use. The processing includes proper burning and grinding of the materials under carefully controlled conditions to form the amorphous form of silica which is important to their pozzolanic activity. The temperature and duration of burning are important in processing $[4,6,8]$. Calcination and pyroprocessing technologies are therefore very important for the development of low-cost cement.

\subsection{Cement Production Processes}

1.1.1. General Overview of Principles. The wet and dry manufacturing processes are the two main ways of manufacturing cement [2]. The major difference between wet and dry process is the mix preparation method before burning clinker in the kiln. The wet process involves the addition of water to the raw materials to form rawslurry which is thick. In the dry process, the raw materials are prepared by fine grinding and drying. The choice of the process is mainly dependent on the nature of the raw materials available. When the moisture content in raw materials is more than $20 \%$, the wet method is preferred to the dry method [9]. Figure 1 shows a process scheme that would apply to both the dry and the wet processes.

In the past, the wet process was mostly used since homogenization of wet raw materials was easier than that of dry powders. In the wet process, there is an easier control of the chemical composition of the raw materials. This process is however more energy-intensive and hence more expensive compared to the dry process given that the wet slurry has to be evaporated before the process of calcination. The total heat requirements for the dry precalciner kilns are much lower compared to the former wet process kilns. With about $900 \mathrm{kcal} / \mathrm{kg}$ compared to about $1600 \mathrm{kcal} / \mathrm{kg}$ for the wet process kilns, the new dry processes are less expensive in terms of heat requirement (about 60\% less) [11]. With this reason, many old wet process kilns have been converted into dry process plants. Mostly, semiwet and semidry process kilns are intermediate steps in the conversion. Over the years, wet process plants have been converted to dry ones especially in Europe. By 2004, dry process kilns accounted for $90 \%$ of all process technologies used. Figure 2 shows global clinker production per kiln type by the year 2009 .

1.2. Preparation of Raw Materials. The prime raw material which is limestone is broken into big boulders after blasting in mines [13]. It is then transported by dumpers to a limestone crusher where it is crushed to between 15 and $20 \mathrm{~mm}$ size. The material is then crushed and piled longitudinally by equipment called stacker/reclaimer. The crushed limestone from pile is transported through the belt conveyer to the hopper. Similarly, other raw materials like clay, bauxite, and iron ore are also transported by a conveyer belt from the storage yard to the respective hoppers. All raw materials are proportioned in requisite quantity through weigh feeders. The proportioned raw materials are then transported by a conveyor belt to the raw mill to be ground into the powder form. After grinding, the powdered raw mix is stored in a raw meal-silo where blending takes place.

Raw material preparation provides a mixture of raw materials and additives that has the right chemical composition and particle size distribution necessary for clinker production [13]. For plants that receive their raw materials already crushed, this stage usually involves grinding (milling), classification, mixing, and storage [13]. Raw material preparation is an electricity-intensive production step requiring about 25 to 35 kilowatt hours (kWh) per ton of raw material, although it could require as little as $11 \mathrm{kWh}$ per ton. After primary and secondary size reduction, the raw materials are further reduced in size by grinding. Grinding differs with the pyroprocessing process (kiln type) used. In dry processing, the materials are ground into a powder that can flow in horizontal ball mills or in vertical roller mills. In a ball mill, steel-alloy balls are responsible for decreasing the size of the raw material pieces in a rotating cylinder. Rollers on a round table provide size reduction in a roller mill. Waste heat from the kiln exhaust or the clinker cooler vent, or auxiliary heat from a standalone air heater before pyroprocessing, is often used to further dry the raw materials. The average moisture content in the raw material feed of a dry kiln typically varies between $0 \%$ and $0.7 \%$ [13].

1.3. The Kiln Processes. Portland cement is mostly made in a rotary kiln [14]. Basically, this is a long cylinder rotating about its axis once every one or two minutes. This axis is inclined at an angle, with the burner being lower at the lower end. Raw mix is fed in at the upper end, and the rotation of the kiln causes it to move gradually downhill to the other end of the kiln. Figure 3 shows a general layout of a rotary kiln [15].

There are three types of rotary kilns: kiln without preheater, kiln with preheater $(\mathrm{PH})$, and kiln with both preheater and precalciner (PC). Kilns with $\mathrm{PH}$ are preferred to kilns without $\mathrm{PH}$ as they have lower energy consumption. For this reason, long rotary kiln without PH (long dry kilns) are being replaced over time. Thermal energy requirement is further reduced if a $\mathrm{PH}$ kiln is also equipped with a PC. New facilities usually include both $\mathrm{PH}$ and $\mathrm{PC}$. A preheater $(\mathrm{PH})$ is series of vertical cyclones in which the material is passed in counterflow with exhaust gases from the rotary kiln so that heat is transferred from the hot gas to the raw meal, which is therefore preheated and even partially calcined before entering the rotary kiln.

The four-stage cyclone preheater kiln system was the standard technology in the 1970s since most plants were built in the range of 1000 to 3000 tons/day production. However, a number of different SP kilns are available. Most 


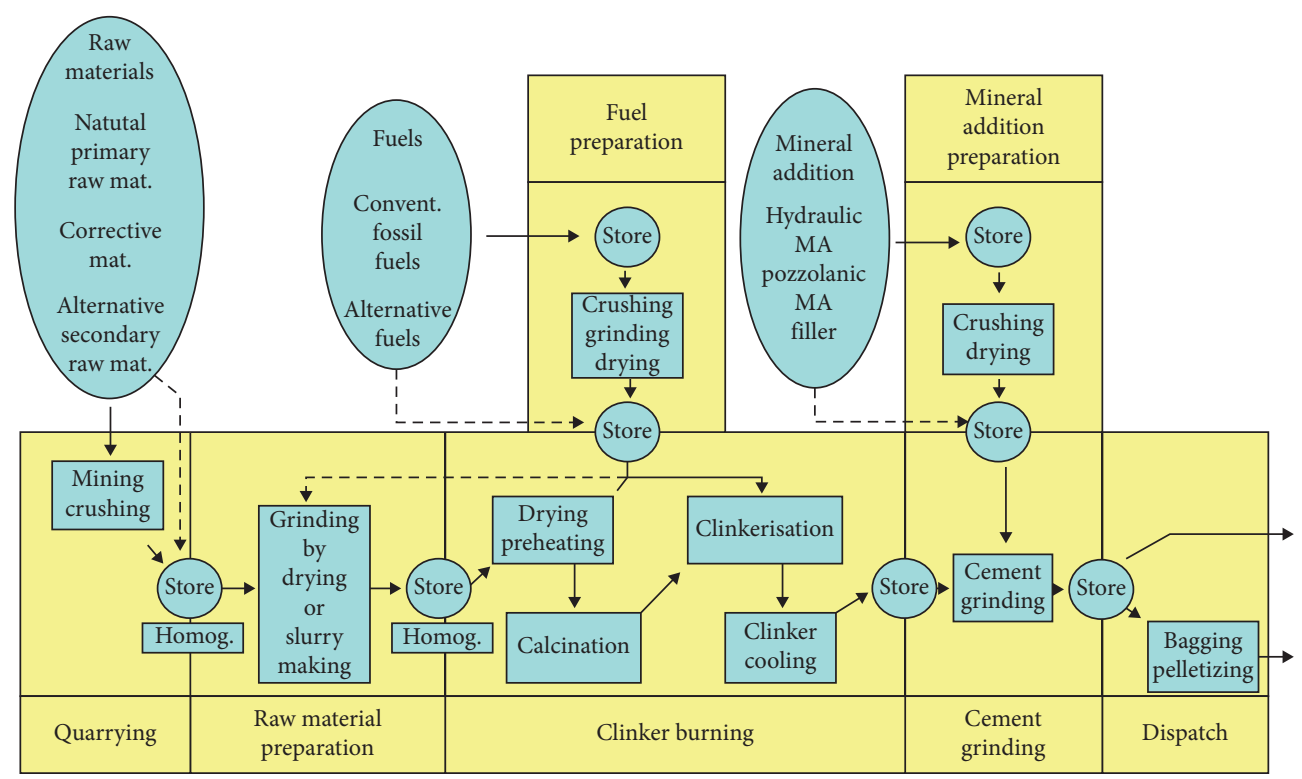

FIgURE 1: Simplified cement production process [10].

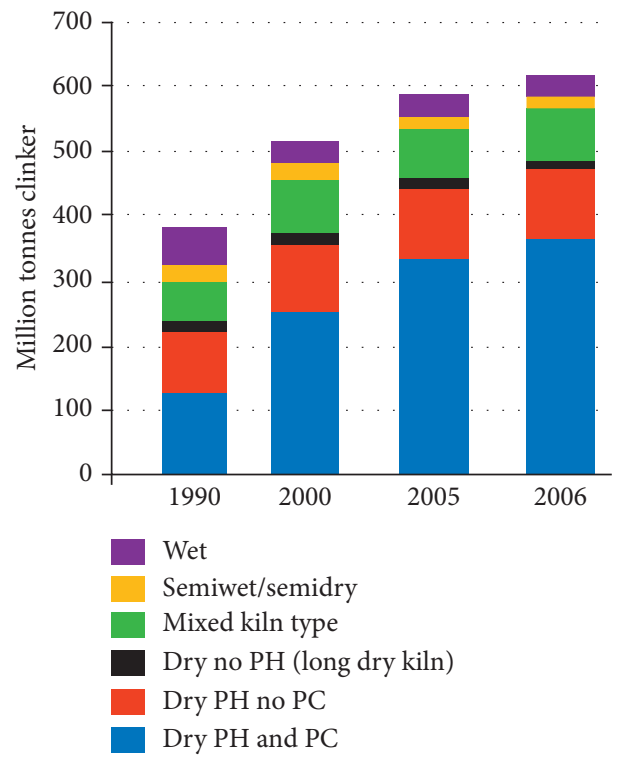

FIGURE 2: Global clinker production per kiln type according to the GNR database [12].

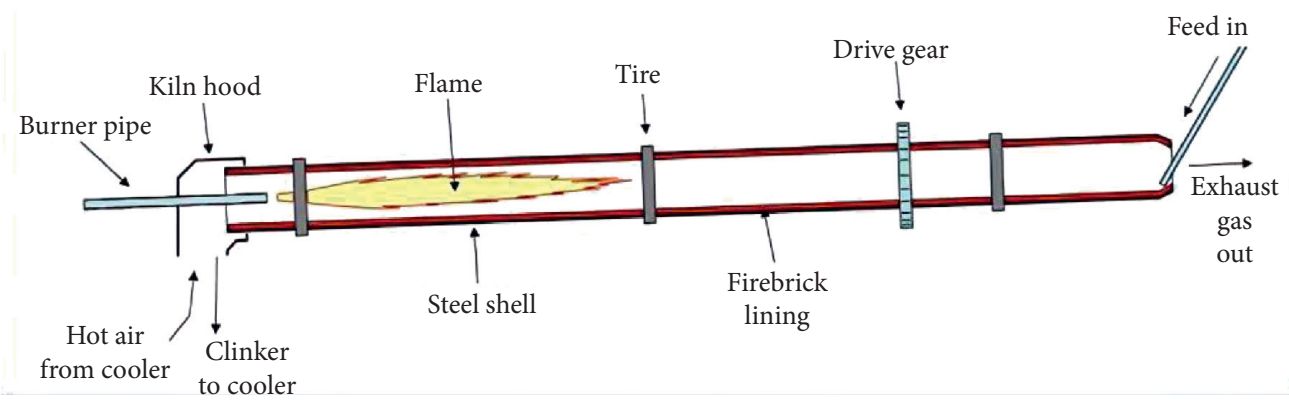

Figure 3: General layout of a rotary kiln [15]. 
common SP kilns have between 4 and 6 cyclone stages. The moisture content of the raw materials determines the number of stages. Where moisture is less than $8.5 \%$, a $\mathrm{PH}$ kiln with 4 to 6 stages may be used. The higher the number of cyclone stages, the more the heat recovered. The energy demand of a 6-stage cyclone $\mathrm{PH}$ is about $60 \mathrm{MJ} / \mathrm{t}$ less than the demand of a 5-stage $\mathrm{PH}$, and a 5-stage $\mathrm{PH}$ would save approximately $90 \mathrm{MJ} / \mathrm{t}$ over a 4 -stage $\mathrm{PH}$. The addition of a 4th cyclone stage to a 3-stage $\mathrm{PH}$ may decrease the energy needs by $250 \mathrm{MJ} / \mathrm{t}$, but moisture in the raw materials should not exceed $8.5 \%$. If this is the case, a 3-stage cyclone is preferred as the thermal efficiency will not improve when an extra stage is added. The SP unit has a typical unit capacity between 300 and $4000 \mathrm{t} / \mathrm{d}$ [14]. In general, a PH tower consists of 1 to 6 cyclone stages, which are disposed one above the other in a tower. The PH kiln performance can be extended using precalcination technology. For the time being, kiln systems with multistage cyclone preheaters and a precalciner are considered to be the state-of-the-art technology for new dry process plants. Precalciner kilns first appeared in the 1970s. The calciner is a secondary combustion device where the total fuel is burnt. In this chamber, about $60 \%-65 \%$ of the total kiln emissions are released, while limestone $\left(\mathrm{CaCO}_{3}\right)$ is decomposed into lime $(\mathrm{CaO})$ and carbon dioxide $\left(\mathrm{CO}_{2}\right)$. The remainder of the emissions is generated from fuel combustion. As calcination is at least $90 \%$ completed when the raw meal is fed into the rotary kiln, the PC technique allows a considerable increase in the clinker capacity. The average capacity of new European plants ranges from 3000 to 5000 tons of clinker per day. However, from a technical point of view, capacities of up to 15,000 tons per day are feasible. Three PH/PC kilns with a capacity of 10,000 $\mathrm{t} / \mathrm{d}$ are currently in operation in Asia. The addition of a PC also reduces the energy requirements. The $\mathrm{PH} / \mathrm{PC}$ kiln is the most energy-efficient kiln technology. Thermal energy demands for different kilns are listed in Tables 1 and 2. Other kinds of kilns include equipment for semidry and semiwet processes [16].

For semidry processes, the Lepol kiln (300 to 2000 tons/ day) - where a travelling grate preheater is installed outside the rotary kiln-requires less thermal energy than a long dry kiln $(300-2800 \mathrm{t} / \mathrm{d})$. In semiwet processes, a filter cake is produced from raw material handling. This cake is either extruded to pellets prior to being fed to the Lepol kiln or loaded into a cyclone SP/PC kiln after being dried to a raw meal in an external dryer. This latter system offers both the lowest heat consumption and the highest clinker capacity (2000-5000 t/d compared to $300-3000 \mathrm{t} / \mathrm{d}$ ). If wet raw material preparation is required, a 2 -stage $\mathrm{PC}$ with the dryer (2000-5000 $\mathrm{t} \mathrm{cli/d)} \mathrm{can} \mathrm{provide} \mathrm{the} \mathrm{lowest} \mathrm{thermal} \mathrm{energy}$ consumption. The wet slurry is first dried in an integral dryer crusher, after which it is fed to the PH-PC kiln. This modern process is replacing the conventional method which comprises the long wet rotary kiln $(300-3600 \mathrm{t} / \mathrm{d})$ with an internal drying/preheating system [14].

The fluidized-bed cement kiln (FB) is a recent technique that is emerging. It has been used in Japan since 1989 on a pilot basis. It has a capacity of 20 tons per day. A larger capacity FB of 200 tons/day was developed in 1996 [19]. In
TABle 1: Thermal energy consumption for dry kilns (GJ/t).

\begin{tabular}{lcccc}
\hline \multicolumn{5}{c}{ Dry kilns with $P H$ and PC } \\
\hline Kiln type & BREF, [17] & CSI, [12] & Cembureau, [10] & IEA, [18] \\
\hline 3-6 stages & $3-3.95$ & 3.4 & $2.9-3.2$ \\
\hline \multicolumn{5}{c}{ Dry kilns with PH only } \\
\hline 1-4 & $3.1-4.2$ & 3.7 & $3.1-3.5$ \\
\hline
\end{tabular}

China, a pilot kiln with a capacity of $1000 \mathrm{t} / \mathrm{d}$ is now under construction. Compared to the SP kiln with the grate cooler, the FB kiln could reduce the heat consumption by $10-12 \%$, but it is not expected to serve large capacities and is not yet available for the cement industry. Figure 4 shows a fluidizedbed advanced cement kiln system [20].

The technology offers the following advantages:

(i) It reduces emission of $\mathrm{CO}_{2}$ because of the reduction of fuel consumption

(ii) It is able to use low-grade coal such as low volatile and low calorific value coal since it has improved burning and heat transfer

(iii) It has an improved heat recovery efficiency due to increase in waste heat recovery

(iv) Since there are no movable apparatuses, construction and maintenance costs are decreased

(v) The system is able to control temperature more tightly and keep longer reaction time, and it enables quality improvement and production of special cement of higher grade

(vi) Thermal $\mathrm{NO}_{X}$ emission can greatly be decreased since combustion takes place in the fluidized bed without generating flame [19]

1.4. The Cement Grinding Process. Cement grinding process is the reduction of clinker produced in rotary kilns to a fine form. The clinker has to be ground with the addition of gypsum to get the finish product, cement. The objective is to increase the specific surface of the cement component with a proper particle size distribution and to provide convenient reactivity of cement making it more easily workable when used in concrete [21].

1.5. Grinding Technologies in the Cement Industry. Grinding systems in the cement industry play an important role in the distribution of the particle size and particle shape [22]. The size and shape of the cement particles affect the reactivity of the clinker. They also affect the dependence on temperature of dehydrating gypsum that is ground together with the clinker. These factors affect the mortar properties of the cement product such as water demand, initial and final setting times, and strength development [23]. Ball mills have been used as the main grinding equipment for finished cement production for over 100 years. Although simple to operate and costcompetitive relative to other technologies, the low efficiency of ball milling is one of the main reasons for the 
TABLE 2: Thermal energy consumption for different kinds of kilns (GJ/t).

\begin{tabular}{lccc}
\hline Kiln type & BREF, [17] & CSI, [12] & Cembureau, [10] \\
\hline Long dry & $<5.0$ & 4.49 & $3.6-4.5$ \\
Long wet & $5.0-6.4$ & 6.34 & $5.0-7.5$ \\
Lepol semidry/semiwet & $3.3-5.4$ & 3.85 & Semidry: 3.2-3.6 \\
2-stage PC with the dryer (wet) & & Semiwet: $3.6-4.5$ \\
3-4 stage SP and PC with the dryer (semiwet) & & $4.5-50$ \\
\hline
\end{tabular}

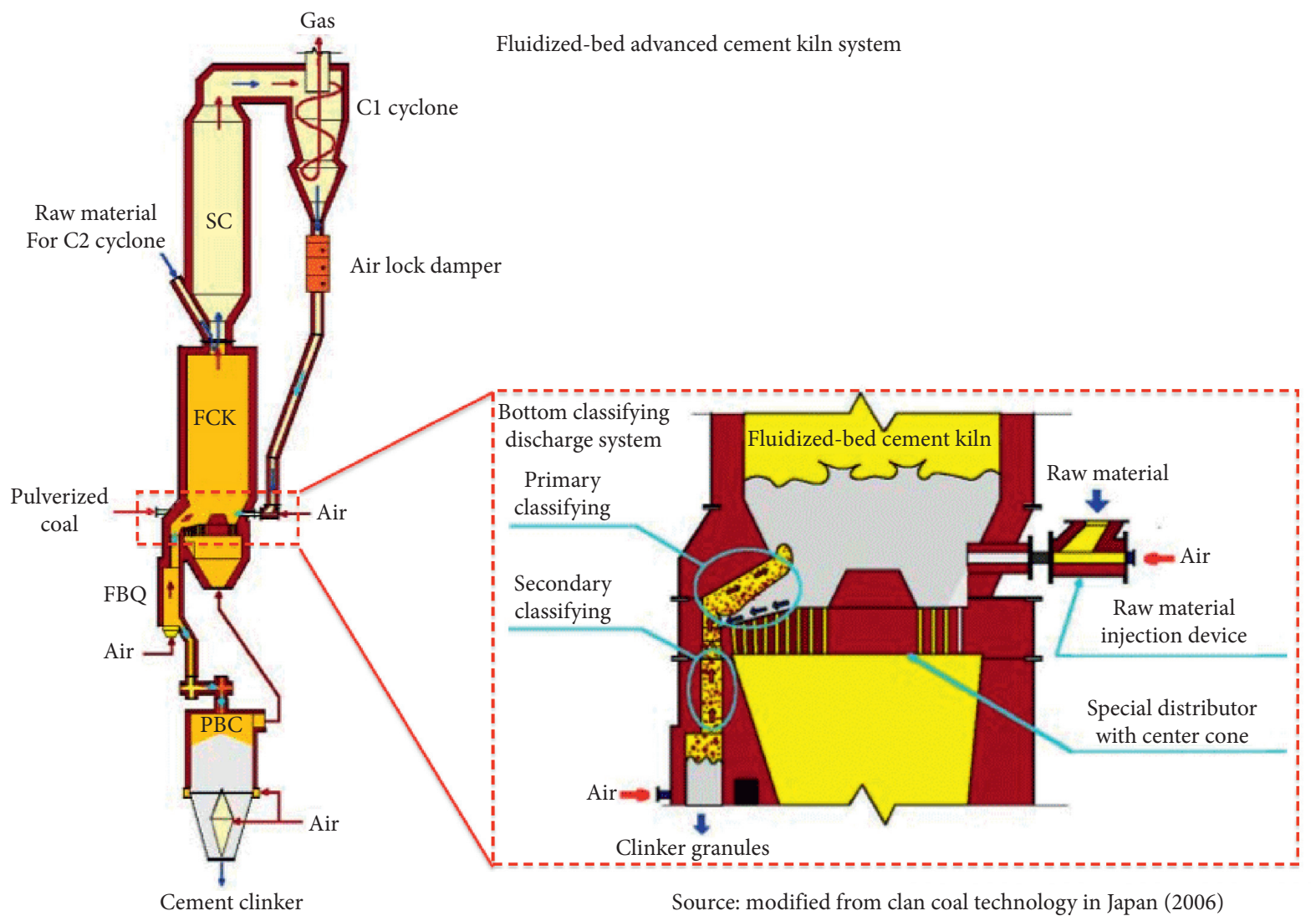

FCK: Fluidized-bed cement kiln

FBQ: Fluidized-bed quenching cool

PBC: Packed-bed cooler

FIGURE 4: Fluidized-bed advanced cement kiln system [14].

development of more efficient grinding processes in recent years. Vertical roller mills (VRMs), high-pressure grinding rolls (HPGRs), vertical shaft impact (VSI) crushers, and more recently, the horizontal roller mill (HOROMILL) (in which energy consumption is substantially reduced) have resulted in an improvement between 45 and $70 \%$ in specific energy related to a typical ball mill [24].

1.5.1. The Ball Mill. Ball mills or tubular mills are built with diameters up to 6.0 meters and lengths up to 20 meters; the drive ratings today are as high as $10,000 \mathrm{~kW}$ with stable operation, and maintenance of a ball mill is relatively simple [25]. The maintenance cost and the capital cost are relatively low compared to other technologies. Due to the high levels of operational reliability and availability, ball mills remain the most frequently applied finishing grinding unit in cement plants. Compared with newer milling devices such as VRM and HPGR, ball mills have the highest specific power consumption and the lowest power utilization (about 32-35 kWh/ton depending on the material hardness and to fineness between 3,000 and $3,200 \mathrm{~cm}^{2} / \mathrm{g}$ ). Most of the energy is lost as a result of heat from the collision of the steel balls among themselves and against the mill walls. Portland cement production is usually finished using a two-compartment ball mill as shown in Figure 5. First compartment or chamber 01 is 


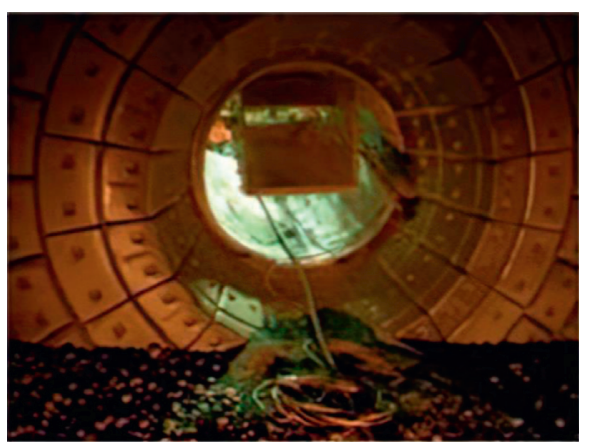

(a)

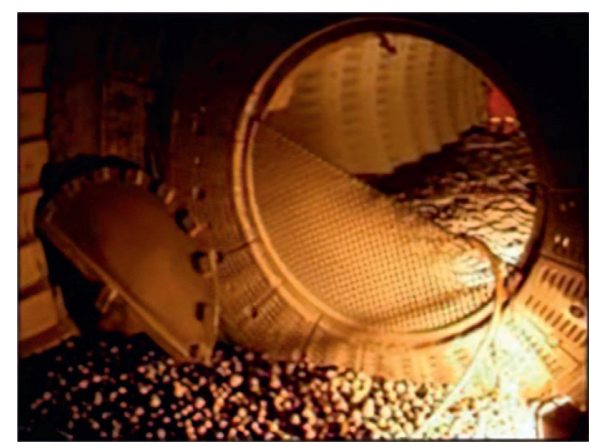

(b)

Figure 5: Two-compartment tube ball mill. (a) Compartment 01. (b) Compartment 01/02 and separating diaphragm [26].

known as the coarse chamber, and in the second compartment, the material is finely ground [26]. Between the two compartments, there is a classification diaphragm that screens the fine form of the coarse material.

Generally on cement mills, the product is ground dry in a ball mill. It has a relatively wider particle size distribution; hence, it is required to operate the ball mill in a closed circuit with a size classifier with an efficient or sharp cut of the size separator. This happens especially when high levels of fines are generated, when mixtures have low Bond work index, or grinding materials that have a tendency to agglomerate due to overgrinding effect. The circulating loads range from $100 \%$ up to $600 \%$ that are established based on the grindability of the new feed, the cut size, and the required product fineness in relation to reaching the adequate cement strength. The energy efficiency of dry ball-mill grinding of cement depends on factors such as ball charge fill-ratio, mill length/diameter ratio, size distribution of the ball charge, operating conditions of the air separators, air flow through the mill, production rate, use of grinding aids, and the hardness and fineness of the feed and product (generally referred to as the work index $(\mathrm{kWh} / \mathrm{t})$ and the F80 and P80 sizes, respectively).

1.5.2. High-Pressure Grinding Roll. In high-pressure grinding roll (HPGR), the material is reduced by a highly compressive stress created by two counter-rotating rolls (one fixed and another floating) [27]. This creates a critical fracture process that presses the material into a compact flow area. This flow area is shown in Figure 6. The grinding pressure between the rolls is 50 to $350 \mathrm{MPa}$, and the circumferential speed of the rolls varies between 1 and $2 \mathrm{~m} / \mathrm{s}$ on the grindability characteristics of the feed and the pressure applied to the roll; the compacted cake (consisting of over $70 \%$ solids by volume) has a fine fraction below $90 \mu \mathrm{m}$. Up to $40 \%$ of these fines must be recovered by deagglomeration of the compacted cake using another deagglomerating device. The specific power utilization is between 14.6 and $19.8 \mathrm{kWh} /$ $\mathrm{t}$ at a Blaine area $3,000-3,200 \mathrm{~cm}^{2} / \mathrm{g}$. HPGRs are reported to be $45-60 \%$ more efficient than ball mills [27].

Trouble-free operation of an HPGR depends to a great extent on ensuring proper moisture below 3\%, and the maximum particle size of the material should not exceed 1.5 to 2 times the gap width. Feed is distributed evenly along the rolls; and foreign material (scats) is not allowed to pass into the rolls and is captured using a magnetic separator system. HPGR is convenient to comminute materials that are not overly fine and have low moisture content [28]. Materials above 3\% moisture must be predried before feeding to the rolls. HPGR can be integrated into various circuit configurations in new and existing grinding plants to increase the output of plants that have only ball mills with precrushing before a ball mill [29].

1.5.3. Vertical Roller Mill (VRM). Vertical roller mills (VRMs) with integrated classifiers have been used successfully for many years in cement plants to grind and dry raw materials simultaneously with moisture contents up to $20 \%$ by weight. Their production can be as high as 400 tons per hour, and they have a drive power of 11.5 megawatts [28]. The feed is comminuted by pressure and friction between a horizontal rotating table and 2 to 4 grinding rollers hydraulically pressed against the table as shown in Figure 7. Nowadays, the grinding rollers have diameters as large as $2.5 \mathrm{~m}$. The material being ground is carried by pneumatic and mechanical transport to the classifier located in the same housing directly above the grinding chamber. The classifier tailings (oversize rejects) are recycled back into the grinding chamber together with the fresh material. The grinding elements and mill settings are modified to grind harder materials such as clinker and granulated blast-furnace slag. Power use is between 26 and $29 \mathrm{kWh} / \mathrm{t}$ when grinding to a Blaine area $3,300 \mathrm{~cm}^{2} / \mathrm{g}$ using a VRM [28].

Vertical roller mills integrate the grinding, drying, and separation processes into one unit. This integration makes the VRM competitive in terms of specific electrical power consumption compared against other technologies. VRM is $50 \%$ more efficient than ball mills when comparing $\mathrm{kWh} / \mathrm{t}$ used to grind the same product under similar service properties [30].

1.5.4. Horizontal Roller Mill. The horizontal roller mill or tube has a length/diameter ratio around 1.0 and is supported and driven on axial bearings [31]. A solid single armored grinding roller is pressed hydraulically against the rotating 


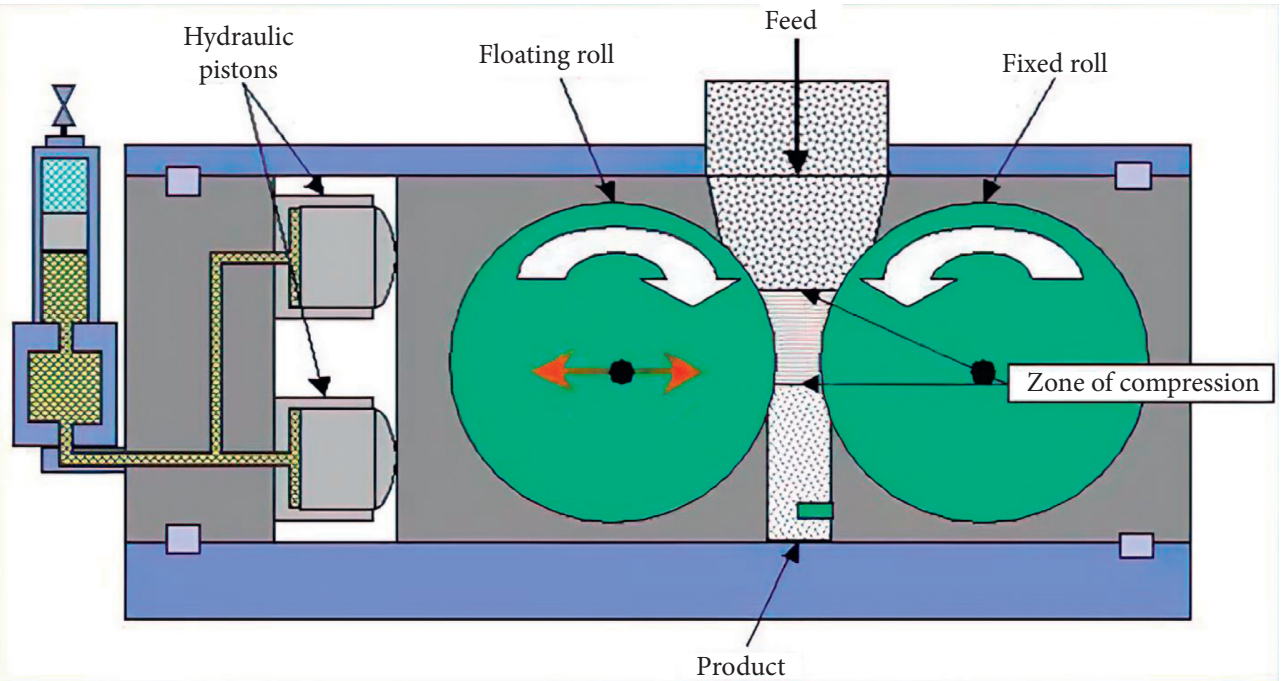

FIGURE 6: High-pressure grinding roll (KHD Humboldt Wedag, 2011).

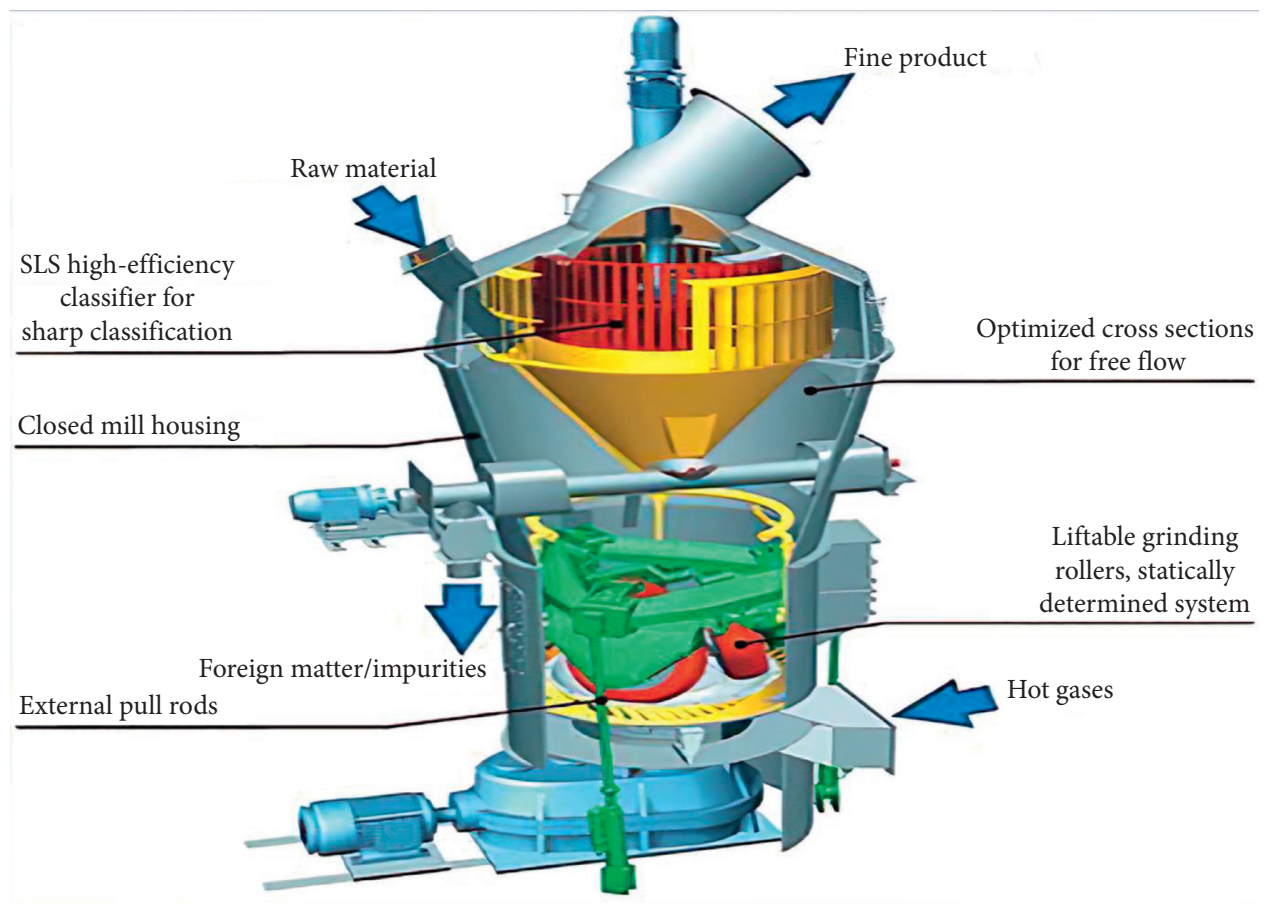

Figure 7: Vertical roller mill.
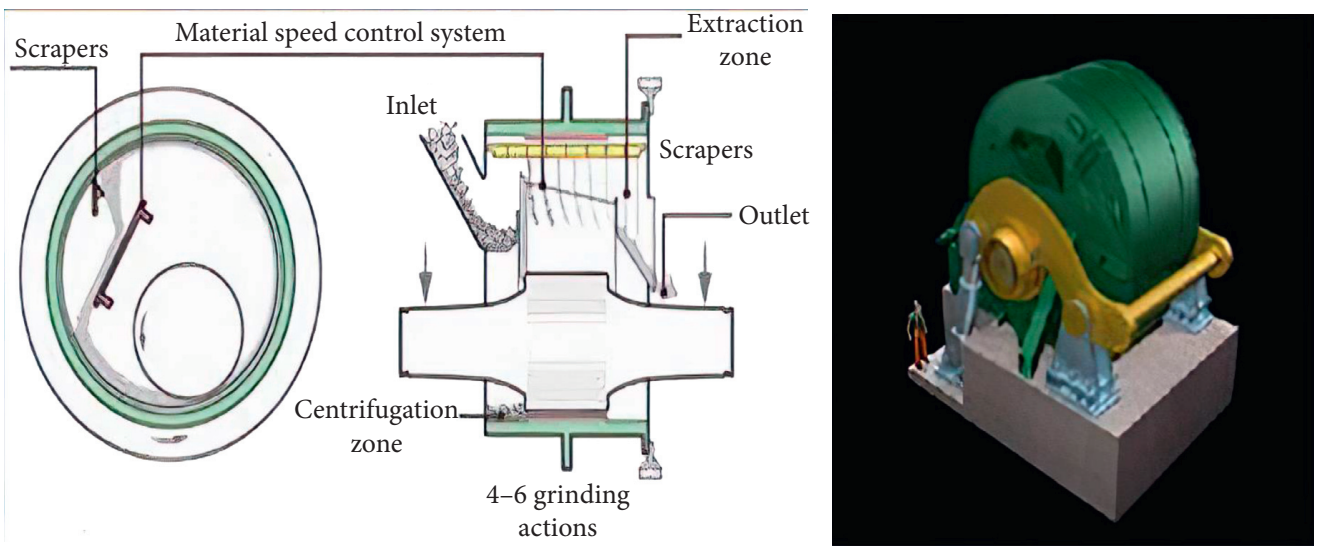

FIgURE 8: HOROMILL schematic diagram. 
inner drum surface within a cylindrical grinding zone as shown in Figure 8. The pressure is much lower than the HPGR and is comparable to the VRM. No compacted cake is produced that requires further deflaking. The grinding roller is supported on bearings outside the grinding tube. Internal fittings are subjected to heavy wear; however, wear of the grinding elements is still lower with the VRM. Power consumption on the horizontal roller mill when compared against a ball mill is reduced by 10 to $25 \mathrm{kWh} / \mathrm{t}$ of cement depending on clinker grindability and Blaine specific surface area [31].

\section{Calcination}

Calcination is the process of changing the chemical composition of a mineral ore by a thermal process or driving off a volatile fraction. Compared to pyrolysis, the absence of oxygen is not necessary in this process [32]. Rotary kilns that are directly heated or those that are indirectly heated are both used for calcination. Calcination is mostly applied in the cement industry. It is carried out in furnaces, also referred to as kilns or calciners, of various designs including shaft furnaces, rotary kilns, multiple hearth furnaces, and fluidized-bed reactors. The first step in cement manufacturing is calcination of calcium carbonate followed by burning resulting calcium oxide together with silica, alumina, and ferrous oxide after mining and grinding [33].

Calcination is commonly used in activating supplementary cementitious materials such as clays. Such clay materials are pozzolana. These are materials that are not cementitious themselves but in finely divided form which react with lime at ambient temperatures to form compounds with cementitious properties [34]. For them to attain pozzolanic properties, these clays were activated by calcination at temperature ranges between 600 and $900^{\circ} \mathrm{C}$ [35]. At these temperatures, the crystal structures of their silicates are transformed into amorphous compounds that react with lime at room temperature to form cementitious materials. Not all types of clays can be calcined to present pozzolanic activity. Clays containing high proportions of crystalline minerals such as quartz and feldspar do not produce reactive material [36]. Temperature control is the key during calcination of the clays to avoid formation of crystalline silicate compounds that would otherwise not react with lime at room temperature $[37,38]$.

2.1. Operation with Conventional Fuels. Cement production is an energy-intensive process consuming thermal energy of the order of $3.3 \mathrm{GJ} /$ ton of clinker produced [39]. Electrical energy consumption is about $90-120 \mathrm{kWh} /$ ton of cement. Coal has been the key fuel in the cement industry for a long time. A wide range of other fuels such as gas, oil, liquid waste materials, solid waste materials, and petroleum coke have all been successfully used as sources of energy for firing cementmaking kilns, either on their own or in various combinations. Since clinker is brought to its peak temperature mainly by radiant heat transfer and a bright (i.e., high emissivity) and hot flame is essential for this, high carbon fuels such as coal which produces a luminous flame are preferred for kiln firing. In favourable circumstances, high-rank bituminous coal can produce a flame at $2050^{\circ} \mathrm{C}$. Natural gas, which can produce a peak temperature of $1950^{\circ} \mathrm{C}$ and being also less luminous, tends to result in lower kiln output [40].

2.2. Alternative Fuels. Apart from the primary fuels above, various combustible waste materials have been used for calcination in kilns. These alternative fuels (AF) include used motor-vehicle tires, sewage sludge, agricultural wastes, landfill gas, refuse-derived fuel (RDF), and chemical and other hazardous wastes [41].

Cement kilns are an attractive way of disposing of hazardous materials because of the following:

(i) The much higher temperatures in the cement kilns are more suitable to effectively dispose the materials than in other incinerators

(ii) The alkaline conditions in the kiln, afforded by the high-calcium raw mix, which can absorb acidic combustion products

(iii) The ability of the clinker to absorb heavy metals into its structure

Use of scrapped motor-vehicle tires which are very difficult to dispose by other means is a good example of an alternative fuel. Whole tires are commonly introduced in the kiln by rolling them into the upper end of a preheater kiln or by dropping them through a slot midway along a long wet kiln. In either case, the high gas temperatures of between $1000^{\circ} \mathrm{C}$ and $1200^{\circ} \mathrm{C}$ cause instant, complete, and smokeless combustion of the tire. Alternatively, tires are chopped into 5-10 mm chips, in which form they can be injected into a precalciner combustion chamber. Steel and zinc in the tires become chemically incorporated into the clinker, partially replacing iron that must otherwise be fed as the raw material. High-level monitoring of both the fuel and its combustion products is necessary to maintain safe operation [40].

2.3. Self-Calcination of Wastes to Make Pozzolana. Natural pozzolanas such as volcanic tuff and silica fume are used in their natural form. Artificial pozzolanas have to be processed before they are used. One way of processing materials to the pozzolanic form is by incineration of agricultural wastes such as rice husks, rice straw, sugarcane bagasse, and ground nut shells, among others. The incineration of these materials decomposes organic matter in the form of cellulose and lignin leaving an ash rich in silica $[42,43]$. When this is done under controlled temperature conditions, the ash is a very good pozzolanic material.

Calcination is another method of processing pozzolana. Materials are heated in a temperature range of $600^{\circ} \mathrm{C}-900^{\circ} \mathrm{C}$. Most work reported on calcination of pozzolana has been on a laboratory scale [41, 44-46]. An industrial trial of calcination of pozzolanas has been reported [41]. In this case, clays were calcined in a wet-process clinker rotary kiln normally used for clinker production. Several technological 
parameters were adjusted in order to calcine the material within the optimal temperature range of $750-850^{\circ} \mathrm{C}$ and not to exceed $900^{\circ} \mathrm{C}$. The Ghanian experience has seen production of clay pozzolana at a small-scale level. In this case, the raw clay was ground and mixed with palm kernel shells, which are local agricultural waste. The shells were incorporated as a source of energy and to increase the ash content. They were processed by a vertical draft kiln that required another external of fuel. The clay pozzolana processed at a temperature of $900^{\circ} \mathrm{C}$ was the best [47]. The optimum replacement range of the clay pozzolana with OPC was between 20 and 25\%. This achieved the Portland pozzolana cement standard with up to a compressive strength of 24.1 MPa and $28 \mathrm{MPa}$ at $28^{\text {th }}$ day and $60^{\text {th }}$ day of curing. This prototype plant was very promising. However, the kiln used required external fuel, and it was recommended that a kiln in which agricultural wastes be used as a source of fuel be used.

Self-calcination is a process of activating artificial pozzolana in the case where the materials being processed are the ones that produce the energy required for both calcination and incineration. This can be made possible when a material is pozzolanic but can burn by itself or is blended with another material that cannot burn by itself. In this case, the material produces the required heat for processing, and it processes itself to a pozzolanic form. Typical example is rice husk-clay mixes. Laboratory trials have been done before using Kenyan clay-rice husk mixes [48-50].

Agricultural and industrial wastes have been reported as potentially pozzolanic materials when processed under special conditions. Muthengia [42] reported that broken bricks (BB), spent bleaching earth (SBE), and rice husk $(\mathrm{RH})$ can be processed in blend to make good-quality pozzolana. In this work, the materials were activated by self-calcination. This was possible because the blended mix had $\mathrm{RH}$ which burns on its own and SBE which contains residual oils from the industrial filtering process. Incineration of $\mathrm{RH}$ alone generates about $15 \mathrm{~J} / \mathrm{g}$ heat [42], while the calorific value of $\mathrm{SBE}$ is about $13.23 \mathrm{~J} / \mathrm{g}$ [55]. In this case, therefore, no external source of energy was required other than small fire for ignition. The materials were incinerated in a special kiln known as the fixed bed kiln (FBK), designed by Ochung'o [51], for incinerating rice husks to form highly pozzolanic rice husk ash. They were left to burn overnight and were collected the following day. They were blended with hydrated lime to form pozzolana-lime cement. Muthengia [49] showed from this work that the blend in which the pozzolana-lime ratio was 2:1 showed the greatest reactivity. Table 3 shows the compressive strength of pozzolana: hydrated lime cements of various individual pozzolana and the combined blends.

From the table of results of compressive strengths, SBE was a spent bleaching earth from an oil refinery in Nairobi. Broken bricks from two companies in Nairobi were used, with G45-BB from Githurai 45 and CW-BB from Clay Works Manufacturers Limited, also in Nairobi, Kenya. RH was used to activate the BB and the SBE in what was called $\mathrm{RH}$ : BB : SBE raw blend. From this work, it was noted that an ideal proportion would be the one with the highest proportion of $\mathrm{SBE}$, then $\mathrm{BB}$, and with the least $\mathrm{RH}$ because of
TABle 3: Compressive strength of pozzolana-lime cements at $7^{\text {th }}$ and $28^{\text {th }}$ day of curing.

\begin{tabular}{lcc}
\hline Pozzolana & $\begin{array}{c}7^{\text {th }} \text { day compressive } \\
\text { strength }(\mathrm{MPa})\end{array}$ & $\begin{array}{c}28^{\text {th }} \\
\text { day compressive } \\
\text { strength }(\mathrm{MPa})\end{array}$ \\
\hline SBE & 9.86 & 10.92 \\
CW-BB & 6.27 & 6.28 \\
G45-BB & 12.97 & 13.2 \\
Activated CW-BB & 9.20 & 9.98 \\
Tuff & 8.94 & 8.99 \\
RHA & 5.48 & 5.60 \\
RH : BB : SBE raw & 8.37 & 8.90 \\
blend & & 7.80 \\
RH : BB : SBE & 7.73 & \\
ashed blend & & \\
\hline
\end{tabular}

pozzolanicity of these materials according to their compressive strength as shown in Table 3. However, this was not possible because when $\mathrm{RH}$ is compacted and ignited, its combustion temperatures increase to very high values [52] which would produce predominantly crystalline silica, which is not reactive. Therefore, a workable mix with a $\mathrm{RH}$ : BB : SBE ratio of $5: 1: 1$ was used. Since activating pozzolana makes up for the processing costs of artificial pozzolana, this was seen as the most cost-effective way of processing these pozzolanic materials. The ashed blend consisted of separately activated $\mathrm{RH}, \mathrm{BB}$, and SBE. This was less pozzolanic and would be more costly in terms of activation. The most workable and easy-to-process material was therefore the raw blended mix that would self-calcine. This met the requirements of pozzolana-lime cements as specified by the ASTM No 593 part C standard [53].

Later, Nalobile et al. [49] optimized the ratio of incinerating the blended materials to a ratio of $10: 1: 2(\mathrm{RH}: \mathrm{BB}$ : $\mathrm{SBE})$. This was done by varying the amount of broken bricks added to the mixture from none to a maximum of $6 \mathrm{~kg}$ in a constant mix containing $20 \mathrm{~kg}$ of $\mathrm{RH}$ and $4 \mathrm{~kg}$ of SBE. The new ratio improved pozzolanicity of the materials in terms of reactivity with lime and compressive strength. Acetylene lime sludge, a waste from the acetylene manufacturing company, was used in place of normal hydrated lime which was used in the previous work. The FBK [51] was used in this work as the work done by Muthengia et al. [50]. Table 4 shows the compressive strength of the pozzolana-lime cements obtained in this work.

Together with other tests done [44], this cement conformed to the standard requirements for pozzolana-lime cements as set in ASTM C part 593 [53]. The sample with the highest pozzolanic reaction was used to replace laboratorymade ordinary Portland cement (OPC) at various percentages from $0 \%, 45 \% .46 \%, 48 \%, 50 \%$, and $52 \%$, and their compressive strengths were compared with the Kenyan standard [54]. It was observed that replacement of OPC with up to $50 \%$ of the pozzolana-lime cements met the required standards [55]. This was therefore seen as a promising venture in making Portland pozzolana cement at a lower cost compared to the current methods.

The FBK used in the aforementioned research was small and laborious to work with. A new kiln which is bigger and 
TABle 4: Compressive strength of pozzolana-lime cements with various ratios of $\mathrm{RH}, \mathrm{BB}$, and $\mathrm{SBE}$.

\begin{tabular}{lcc}
\hline $\begin{array}{l}\text { RH }: \text { BB: } \\
\text { SBE ratio }\end{array}$ & $\begin{array}{c}7^{\text {th }} \text { day compressive strength } \\
(\mathrm{MPa})\end{array}$ & $\begin{array}{c}28^{\text {th }} \text { day compressive } \\
\text { strength }(\mathrm{MPa})\end{array}$ \\
\hline $20: 0: 4$ & 6.5 & 8.6 \\
$20: 1: 4$ & 7.1 & 9.5 \\
$20: 2: 4$ & 8.7 & 10.4 \\
$20: 4: 4$ & 8.35 & 8.90 \\
$20: 6: 4$ & 6.3 & 8.8 \\
\hline
\end{tabular}

more efficient than the FBK needs to be designed so that this pozzolana-lime cement can be tested for its production at micro- and small-scale enterprise. This can benefit poor populations in the third-world countries, especially Africa, and in Kenya. This is because in Kenya, the cost of cementing materials is expensive. This has led to urban poor people living in appalling conditions in slum areas. Most of their houses are made of mud, plastic papers, grass, and old and used corrugated iron sheets. This has led to outbreak of diseases such as pneumonia and cholera. Other conditions such as infestation by jiggers are a common phenomenon in these areas and other rural regions.

\section{Conclusions}

From the above discussion, it has emerged that the cement manufacturing and grinding technologies are a large-scale industry with high cost in capital and energy inputs. The kiln processes are advanced and use both electricity and natural fuels which are expensive and limited factors of production. The raw materials used in cement manufacturing are also limited and sometimes rare. The calcination of the raw materials requires external energy input which has contributed to the high cost of cement especially to low-income population in the developing and third-world countries such as those in Africa, Central America, and parts of Asia. The use of self-calcining materials to make cement can be a welcome venture in such cases where the cement raw materials are scarce or the cost of manufacture is prohibitive. Research has shown that it is possible to form pozzolana cement from waste materials such as RH, BB, SBE, and ALS. However, kiln processing of these materials has not been done to test the practicability of production albeit at microand small-scale enterprise (MSE). There is need for research into designing a kiln that would be used to process these materials in rural settings where the cost of cement is high, while these materials are a menacing solid waste.

\subsection{Areas for Further Research}

(i) There is a need to develop alternative cement manufacturing plants that will be possible at microand small-scale enterprise for affordable production of cement using locally available materials

(ii) There is a need for further research to develop a costeffective and efficient kiln to calcine waste materials such as rice husks, spent bleaching clays, broken bricks, and various clays to make pozzolana cement

\section{Data Availability}

The data used to support the findings of this study are available from the corresponding author upon request.

\section{Conflicts of Interest}

The authors declare no conflicts of interest.

\section{Acknowledgments}

This review was part of the research financially supported by the African Development Bank (AfDB) in conjunction with the Ministry of Higher Education in Kenya, through the award of a $\mathrm{PhD}$ scholarship.

\section{References}

[1] J. M. Wachira, J. K. Thiong'o, J. M. Marangu, and L. G. Murithi, "Physicochemical performance of portland-rice husk ash-calcined clay-dried acetylene lime SludgeCement in sulphate and chloride media," Advances in Materials Science and Engineering, vol. 2019, Article ID 5618743, 12 pages, 2019.

[2] H. F. W. Taylor, Cement Chemistry, Thomas Telford, London, UK, Second edition, 1997.

[3] F. Massazza, "Pozzolana and pozzolanic cements A2-hewlett, peter C." in Lea's Chemistry of Cement and Concrete, pp. 471-635, Butterworth-Heinemann, Oxford, UK, Fourth edition, 1998.

[4] J. M. Hernández, B. Middendorf, M. Gehrke, and H. Budelmann, "Use of wastes of the sugar industry as pozzolana in lime-pozzolana binders: study of the reaction," Cement and Concrete Research, vol. 28, no. 11, pp. 1525-1536, 1998.

[5] A. A. Al-Rawas, A. Wahid Hago, T. C. Corcoran, and K. M. Al-Ghafri, "Properties of Omani artificial pozzolana (sarooj)," Applied Clay Science, vol. 13, no. 4, pp. 275-292, 1998.

[6] D. A. Aderibigbe and A. E. Ojobo, "Properties of cupola slag as a pozzolana and its effects on partial replacement of cement in a mortar," Conservation \& Recycling, vol. 5, no. 4, pp. 203-208, 1982.

[7] M. J. Mwiti, T. J. Karanja, and W. J. Muthengia, "Properties of activated blended cement containing high content of calcined clay," Heliyon, vol. 4, no. 8, Article ID e00742, 2018.

[8] E. Opoku Amankwah, "Influence of calcined clay pozzolana on strength characteristics of Portland cement concrete," International Journal of Materials Science and Applications, vol. 3, no. 6, p. 410, 2014.

[9] S. P. Dunuweera and R. M. G. Rajapakse, "Cement types, composition, uses and advantages of nanocement, environmental Impact on cement production, and possible solutions," Advances in Materials Science and Engineering, vol. 2018, Article ID 4158682, 11 pages, 2018.

[10] Best Available Techniques for the Cement Industry, Cembureau, June 2019, http://www.ztch.umcs.lublin.pl/materialy/ batchcement.pdf.

[11] N. Mahasenan, S. Smith, and K. Humphreys, "The cement industry and global climate change: current and potential future cement industry $\mathrm{CO}_{2}$ emissions," in Greenhouse Gas Control Technologies-6th International Conference, J. Gale and Y. Kaya, Eds., vol. 14, pp. 995-1000, Pergamon, Oxford, UK, 2003. 
[12] Cement Industry Energy and $\mathrm{CO}_{2}$ Performance "Getting the Numbers Right,” CSI, 2009, http://ficem.org/CIC-descargas/ Suiza/CSI/Cement-Industry-Energy-and-CO2-Performance_ Getting-the-Numbers-Right.pdf.

[13] J.-H. Xu, B.-W. Yi, and Y. Fan, “A bottom-up optimization model for long-term $\mathrm{CO} 2$ emissions reduction pathway in the cement industry: a case study of China," International Journal of Greenhouse Gas Control, vol. 44, pp. 199-216, 2016.

[14] H. A. Abdel-Gawwad, M. Heikal, M. S. Mohammed et al., "Sustainable disposal of cement kiln dust in the production of cementitious materials," Journal of Cleaner Production, vol. 232, pp. 1218-1229, 2019.

[15] A. A. Boateng, "Heat transfer processes in the rotary kiln bed," in Rotary Kilns, A. A. Boateng, Ed., pp. 173-201, ButterworthHeinemann, Boston, MA, USA, Second edition, 2016.

[16] W.-N. Wu, X.-Y. Liu, Z. Hu, R. Zhang, and X.-Y. Lu, "Improving the sustainability of cement clinker calcination process by assessing the heat loss through kiln shell and its influencing factors: a case study in China," Journal of Cleaner Production, vol. 224, pp. 132-141, 2019.

[17] European Commission, Reference Document on Best Available Techniques in the Cement, Lime and Magnesium Oxide Manufacturing Industries, European Commission, Brussels, Belgium, ftp://ftp.jrc.es/pub/eipccb/doc/clm_brief_0510.pdf, 2010.

[18] International Energy Agency, "Tracking industrial efficiency and $\mathrm{CO}_{2}$ emissions," Energy Technology Transitions for Industry, Strategies for the Next Industrial Revolution, IEA, Paris, France, 2007.

[19] T. Yuko, T. Ikabata, T. Akiyama, T. Yamamoto, and N. Kurumada, "New clinker formation process by the fluidized bed kiln system," Cement and Concrete Research, vol. 30, no. 7, pp. 1113-1120, 2000.

[20] S. Li, Y. Ge, and X. Wei, "Experiment on NOx reduction by advanced reburning in cement precalciner," Fuel, vol. 224, pp. 235-240, 2018.

[21] H. Li, J. Zhao, Y. Huang et al., "Investigation on the potential of waste cooking oil as a grinding aid in Portland cement," Journal of Environmental Management, vol. 184, pp. 545-551, 2016.

[22] O. Altun, "Energy and cement quality optimization of a cement grinding circuit," Advanced Powder Technology, vol. 29, no. 7, pp. 1713-1723, 2018.

[23] N. A. Toprak, O. Altun, and A. H. Benzer, "The effects of grinding aids on modelling of air classification of cement," Construction and Building Materials, vol. 160, pp. 564-573, 2018.

[24] N. A. Aydoğan and H. Benzer, "Comparison of the overall circuit performance in the cement industry: high compression milling vs. ball milling technology," Minerals Engineering, vol. 24, no. 3, pp. 211-215, 2011.

[25] H. Y. Qian, Q. G. Kong, and B. L. Zhang, "The effects of grinding media shapes on the grinding kinetics of cement clinker in ball mill," Powder Technology, vol. 235, pp. 422-425, 2013.

[26] M. Mirhosseini, A. Rezania, and L. Rosendahl, "Power optimization and economic evaluation of thermoelectric waste heat recovery system around a rotary cement kiln," Journal of Cleaner Production, vol. 232, pp. 1321-1334, 2019.

[27] R. Saidur, M. S. Hossain, M. R. Islam, H. Fayaz, and H. A. Mohammed, "A review on kiln system modeling," Renewable and Sustainable Energy Reviews, vol. 15, no. 5, pp. 2487-2500, 2011.
[28] B. A. Wills and J. A. Finch, "Chapter 7-grinding mills," in Wills' Mineral Processing Technology, B. A. Wills and J. A. Finch, Eds., pp. 147-179, Butterworth-Heinemann, Boston, MA, USA, Eighth edition, 2016.

[29] A. Jankovic, W. Valery, and E. Davis, "Cement grinding optimisation," Minerals Engineering, vol. 17, no. 11-12, pp. 1075-1081, 2004.

[30] J.-H. Wang, Q.-R. Chen, Y.-L. Kuang, A. Lynch, and J.-W. Zhuo, "Grinding process within vertical roller mills: experiment and simulation," Mining Science and Technology (China), vol. 19, no. 1, pp. 97-101, 2009.

[31] Ö. Genç and A. H. Benzer, "Horizontal roller mill (Horomill) application versus hybrid HPGR/ball milling in finish grinding of cement," Minerals Engineering, vol. 22, no. 15, pp. 1344-1349, 2009.

[32] J. Plou, I. Martinez, G. Grasa, and R. Murillo, "Reactivity of calcined cement raw meals for carbonation," Powder Technology, vol. 354, pp. 338-347, 2019.

[33] Z. Liu, Z. Wang, M. Z. Yuan, and H. B. Yu, "Thermal efficiency modelling of the cement clinker manufacturing process," Journal of the Energy Institute, vol. 88, no. 1, pp. 76-86, 2015.

[34] J. Bensted and P. Barnes, Structure and Performance of Cements, Spon Press, London, UK, Second edition, 2002.

[35] R. Fernandez, F. Martirena, and K. L. Scrivener, "The origin of the pozzolana activity of calcined clay minerals: a comparison between kaolinite, illite and montmorillomite," Cement and Concrete Research, vol. 41, no. 10, pp. 113-122, 2011.

[36] P. K. Mehta, "Chapter 1: natural pozzolans," in Supplementary Cementing Materials for Concrete, V. M. Malhotra, Ed., vol. 1, p. 428, Minister of Supply and Services, Canada, 1987.

[37] M. S. Barata, "High performance concrete in Pará state: economical and technical viability study on production of high perfomance concrete with the available material in Belém using fume and metakaolin," Master dissertation, Federal University of Minas Gerais, Porto Alegre, Brazil, in Portuguese, 1998.

[38] P. E. Tsakiridis, M. Samouhos, and M. Perraki, "Valorization of dried olive Pomace as an alternative fuel resource in cement clinkerization," Construction and Building Materials, vol. 153, pp. 202-210, 2017.

[39] E. Benhelal, E. Shamsaei, and M. I. Rashid, "Novel modifications in a conventional clinker making process for sustainable cement production," Journal of Cleaner Production, vol. 221, pp. 389-397, 2019.

[40] D. Song, L. Lin, and Y. Wu, "Emergy analysis of a typical New suspension Preheaters cement plant in China," Journal of Cleaner Production, vol. 222, pp. 407-413, 2019.

[41] S. Roger, L. M. Vizcaíno, S. Damas, A. Mathieu, A. Alujas, and F. Martirena, "Industrial calcination of kaolinitic clays to make reactive pozzolans," Case Studies in Construction Materials, vol. 6, pp. 225-232, 2017.

[42] P. Chindaparasirt and S. Rukzon, "Strength, porosity and corrosion resistance of ternary blend portland cement, rice husk ash and fly ash mortar," Construction and Building Materials, vol. 22, no. 8, pp. 1601-1606, 2008.

[43] J. S. Coutinho, "The combined benefits of CPF and RHA in improving the durability of concrete structures," Cement and Concrete Research, vol. 25, no. 1, pp. 51-59, 2003.

[44] M. R. Yogananda and K. S. Jagadish, "Pozzolanic properties of rice husk ash, burnt clay and red mud," Building and Enviroment, vol. 23, no. 4, pp. 303-308, 1988.

[45] A. Chakhouk, B. Samet, and T. Minfi, "Study on the potential use of Tunisian clays as pozzolanic material," Applied Clay Science, vol. 33, no. 2, pp. 79-88, 2006. 
[46] R. Fernandez, K. Scrivener, E. Gallucci, and F. Marirena, "Calcined clay as a reactive pozzolan for cement substation, extended abstracts," in Proceedings of the 27th Cement andConcrete Science Meeting, Royal Holloway, London, UK, September 2007.

[47] K. A. Solomon-Ayeh, E. Atiemo, and T. Amoako-Kutin, Comparative Strengths of Concrete from Clay Pozzolana and Other Blended Cements, The building and Road Research Institute, Accra, Ghana, 2009.

[48] L. J. Kinyua, "Pozzolana cement obtained by calcining raw calys/rice husks mixtures," Msc thesis, Kenyatta University, Nairobi, Kenya, 2013.

[49] P. Nalobile, J. M. Wachira, J. K. Thiong'o, and J. M. Marangu, "Pyroprocessing and the optimum mix ratio of rice husks, broken bricks and spent bleaching earth to make pozzolanic cement," Heliyon, vol. 5, no. 9, Article ID e02443, 2019.

[50] M. M. Washira, M. G. Kanyago, and T. O. J. Karanja, "Cementing material from rice husk-broken bricks-spent bleaching earth-dried calcium carbide residue," Mediterranean Journal of Chemistry, vol. 2, no. 2, pp. 401-407, 2012.

[51] G. J. Ochung'o, "The production of rice husk cementitious materials," Msc thesis, Kenyatta University, Nairobi, Kenya, 1993

[52] S. K. Chopra, S. C. Ahluwalia, and S. Laxmi, “Technology and manufacture of rice husk ash masonry (RHAM) cement," in Proceedings of ESCAP/RCTT Third Workshop on Rice Husk Ash Cement, New Delhi, India, November 1981.

[53] Annual Book of ASTM Standards, Standard Specification for Fly Ash and Other Pozzolanas for Use with Lime (Part C), Vol. 593, American Testing Materials, Philadelphia, PA, USA, 1991.

[54] Kenya Bureau of Standards, Kenya Standard specification For Portland pozzolana Cements KS EAS 18-1, Kenya Bureau of Standards, Nairobi, Kenya, 2001.

[55] P. Nalobile, Investigation of the Pyroprocessing and the Optimum Mix Ratio of Rice Husks, Broken Bricks and Spent Bleaching Earth to Make Pozzolanic Cement, Kenyatta University, Nairobi, Kenya, 2014. 